\title{
14 Conservation-oriented research in the Virunga region
}

ANDREW J. PLUMPTRE \& ELIZABETH A. WILLIAMSON

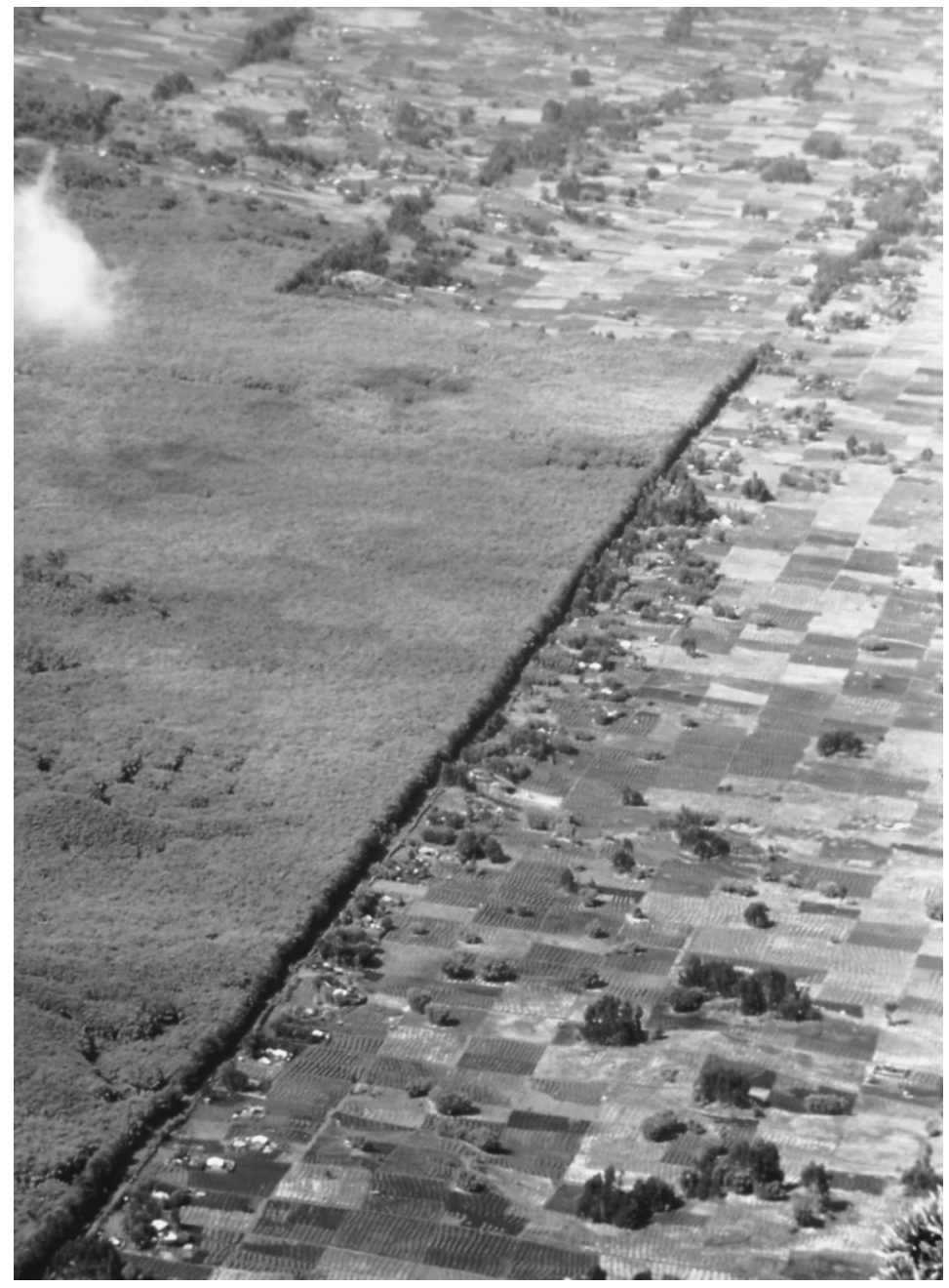

Park/farmland boundary in Parc des Volcans, Rwanda. (Photo by Andrew J. Plumptre.) 


\section{Threats to gorillas in the Virungas during the 20th century}

Gorilla (Gorilla gorilla) populations are threatened throughout their range, primarily by human activities. As human populations increase in Africa the available room for gorillas is decreasing and gorillas are coming into contact with humans much more than they used to. Each of the three subspecies (see chapter 1 for discussion about possible changes in taxonomy), G. g.gorilla (population of about 110000 ), G. g. graueri (population of about 17000), and $G . g$. beringei (population of about 600) are threatened by slightly different factors that result from increasing human populations, and all gorilla populations are considered under IUCN criteria as either vulnerable or endangered (Harcourt, 1996). The major threats to gorillas can be categorized as: (1) habitat loss, modification, or fragmentation; (2) hunting or poaching; (3) disease transmission from humans; and (4) war or political unrest. The mountain gorillas in the Virungas have been exposed to each of these threats over the period during which western scientists have known about them. Despite the international publicity about these animals and despite their potential to earn foreign currency for the countries where they are found, mountain gorillas still face several of these threats. This chapter reviews the threats gorillas have faced in the Virungas over time and summarizes some of the research that has aimed to address these threats and provide information to park managers to better conserve the gorillas. We focus primarily on Rwanda and the Parc National des Volcans because the Karisoke Research Center, where most researchers have been based, is in this country. However we do make comparisons with the rest of the Virungas in Uganda and the Democratic Republic of Congo (DRC) and with the Bwindi Impenetrable National Park in Uganda.

\section{Habitat loss, modification, or fragmentation}

This category of threat includes loss or fragmentation of forest due to agriculture and burning, and degradation of forest through human modification such as logging, fuel wood and non-timber forest product collection, and grazing domestic animals. Today the whole Virunga region, including Ugandan, Rwandan, and Congolese sectors, covers an area of about $430 \mathrm{~km}^{2}$, although much of the high-altitude vegetation is not particularly suitable for gorillas (Weber \& Vedder, 1983). For this population of gorillas to survive they can not afford to lose any more terrain.

When the mountain gorilla was first discovered for western science in 1902 by Oscar von Beringe, its range and available habitat were considerably larger than that which remains today. The land around the Virungas is very fertile, as the soils derive from volcanic deposits, and consequently 
it can support a high human population density. Human populations have increased drastically since 1902 and now the land around the Virunga forests supports 300-600 people per square kilometer, most of whom are subsistence farmers. In 1959, George Schaller carried out the first extensive research on mountain gorillas in the wild. At this time he considered habitat loss to be the greatest danger to the survival of the mountain gorillas (Schaller, 1963). He estimated that there were 400-500 gorillas in the Virungas. Within the next 10 years the total area of the Parc National des Volcans (the Rwandan part of the Virungas - see map in chapter 1) was gradually reduced to $46 \%$ of its original size (Weber, 1987a), so that only $125 \mathrm{~km}^{2}$, less than one-third of the Virunga forest, now remains in Rwanda. The bulk of this habitat loss in Rwanda was due to a pyrethrum project that excised 10000 hectares of land in 1968. All forest between the altitudes of $1600 \mathrm{~m}$ and $2600 \mathrm{~m}$ has been removed from Ruhengeri prefecture, Ruhengeri being the largest town in this region. Weber \& Vedder (1983) estimated a $40 \%-50 \%$ decline in the number of gorillas remaining in 1976-78 following this habitat loss.

Removal of natural forest for agriculture destroys gorilla habitat, but there are additional ways that habitat has been affected in the Virungas. Humans have used the forest extensively in the past as a source of building materials, firewood, water, and grazing land for cattle. Regeneration of the vegetation at high altitudes $(2600-4500 \mathrm{~m})$ in these mountains is slow and consequently even low levels of human activity can have a long-lasting impact. During the 1950s, 1960s, and 1970s, herds of several hundred cattle were grazed in the Virungas and their activities are known to have modified the habitat (Schaller, 1963). Herds of cattle in the Virungas were described by Schaller (1963) as an insidious danger, as their numbers were uncontrolled. In Zaire (now the Democratic Republic of Congo) park authorities shot cattle to deter the pastoralists from entering the park (Schaller, 1963), and in the 1970s Fossey used the same tactics in Rwanda (Fossey, 1983). Fossey worked at a time when the administrative structures she was responsible to in Rwanda were minimal. This allowed her a certain autonomy, and although these measures were drastic, they played a role in the eventual removal of all cattle from the Parc National des Volcans by 1976 (Harcourt, 1986; Ruhengeri residents, personal communications).

In 1979 when plans were announced to clear another $52 \mathrm{~km}^{2}$ for cattle grazing, parkland conversion was considered the greatest threat to the gorillas' survival. A means of making the gorillas "pay for themselves" and protecting the park was needed, and thus a tourism program was planned and developed (Vedder, 1989). 
Today the risk of forest conversion to agriculture is low, although not completely eliminated. There have been suggestions by local political leaders in northwestern Rwanda that parts of the Parc National des Volcans be converted to agriculture or that cattle should be grazed in the park; however, the government has not taken these suggestions seriously. In early 2000, a proposal was made to resettle some refugees from Gishwati forest into the Parc National des Volcans but this decision was reversed by a Government Commission. However, these two incidents do show that without constant vigilance, more land could be lost in future.

\section{Hunting or poaching}

Hunting can be direct or indirect, depending on whether gorillas are targeted or whether they are unintentionally trapped by snares. The major reasons for killing gorillas are (1) meat, (2) capture of animals for zoos, and (3) body parts for trophies or religious rites.

The bushmeat trade in central Africa is currently one of the main threats to western lowland gorillas (G. g. gorilla). An estimated 1.2 million metric tonnes of bushmeat are consumed each year in the range of this animal (Wilkie \& Carpenter, 1999), although gorillas form less than $1 \%$ of this trade. However, where gorillas are hunted regularly, their populations are usually drastically reduced or eliminated (Wilkie \& Carpenter, 1999). It has been estimated that in 1999 about 48\% of the Grauer's gorillas in the montain sector of Kahuzi-Biega National Park were killed for meat as a result of civil strife in DRC (O. Ilambu, personal communication; see Yamagiwa, this volume). Hunting of mountain gorillas for meat has also occurred but rarely. It was thought that many gorillas were killed for food in Zaire (now DRC) during fighting for independence in the 1970s (Weber \& Vedder, 1983). Rwandans and Ugandans traditionally do not consume primate meat but in DRC primates are often eaten.

Infant gorillas were also captured for foreign zoos. For example, in 1968-69, 18 gorillas were killed in attempts to capture of gorilla infants (Fossey, 1983). There have been no known deliberate gorilla killings in Rwanda since 1982; however, gorillas are still very much at risk from poaching even where gorilla tourism has brought in foreign currency. For instance in Uganda in 1995 four gorillas were killed in the Bwindi Impenetrable National Park, allegedly to obtain an infant which was smuggled into DRC for sale.

Poaching of gorillas for trophies (skulls, hands, and feet) and skins to sell to collectors has been another motive to kill them. Mountain gorillas were hunted directly for trophies until quite recently. Von Beringe shot the 
first one to be discovered and Carl Akeley shot several for the American Museum of Natural History in the early 1920s. Akeley then went on to help establish the Virunga National Park, the first park in Africa. Religious beliefs and rites were also behind some killings of gorillas in Africa in the first half of the 20th century and even today mountain gorillas are the only subspecies that is not hunted for their body parts. According to Fossey (1983), poachers hunting for trophies were responsible for twothirds of gorilla deaths during the late 1960s and 1970s in the groups she monitored.

Direct killings of mountain gorillas have been very rare in the last 20 years but indirect killing of mountain gorillas still occurs. Wire and rope snares are set to trap antelopes in the Virungas, and animals that get caught struggle to get free, creating deep cuts to their limbs. If these become infected the animal can easily die.

To combat poachers, Fossey initially tried to thwart their activities by cutting trap-lines and herding gorillas away from areas where snares had been set. In 1978-79 there was an eruption of gorilla killings in the habituated gorilla groups in Rwanda. Prior to these killings anti-poacher patrols were organized ad hoc from Karisoke Research Center. The creation of the Digit Fund following the slaughter of Fossey's favourite gorilla, Digit, gave Fossey a source of funds to employ anti-poaching teams and establish regular patrols. The formation of the Mountain Gorilla Project in Rwanda in 1979 increased and improved patrols and law enforcement and thus discouraged interest in gorilla infants and body parts (Harcourt, 1986; Vedder \& Weber, 1990). The subsequent creation of the regional International Gorilla Conservation Program from the Mountain Gorilla Project led to greater collaboration in ranger patrolling and sharing of information between countries.

\section{Disease transmission from humans}

Gorillas are susceptible to human diseases and many in zoos are vaccinated against the common human ailments. With small populations of gorillas, any infectious disease could devastate the population. Diseases transmitted to immunologically naïve populations have resulted in massive mortality in other species - up to entire populations (Thorne \& Williams, 1988; Macdonald, 1996) and primates are especially vulnerable due to their slow reproductive rates (Young, 1994). Disease outbreaks and subsequent deaths of habituated mountain gorillas include respiratory outbreaks and scabies (Hastings et al., 1991; Kalema et al., 1998). In the closely related chimpanzee (Pan troglodytes) polio and respiratory diseases have occurred (Goodall, 1986). 
The gorillas in the Virungas have probably been exposed to human parasites from the local human population for decades. For many years people used the forest to graze cattle, collect firewood and building poles, and hunt and will have defecated and urinated whilst in the forest. More recently, gorilla ecotourism has increased the potential threat of disease transmission. Whilst most of the international tourists visiting Rwanda are fairly fit, having been inoculated against certain diseases, they may be carrying new viruses for the region, such as influenza. It is these illnesses to which the gorillas have never been exposed that are potentially the most dangerous. If poorly controlled, tourism can also lead to increased stress in the animals, which can increase susceptibility to disease (Hudson, 1992; McNeilage, 1996). While this was recognized as a risk at the start of the tourism program, the loss of habitat was considered a far greater threat to the gorillas at the time and the tourism program was implemented with rules in place to regulate tourist visiting times and the number of tourists per group.

During the war and civil unrest from 1991 to 1998, large numbers of people moved through the Virungas, basing themselves for long periods in the forest, and these people were not subject to any of the controls imposed on tourists. They were poorly nourished, living in harsh conditions, and many died in the park. The magnitude of risk from thousands of people streaming through or living in the park is obviously far greater than that posed by the relatively small numbers of tourists who spend a short time in the park. Disease transmission from both the local human populations and from tourists is treated in greater depth in chapter 13 (Mudakikwa et al.).

\section{War and political unrest}

Civil wars are not a new threat to the conservation of protected areas; however, the participants are much better armed than in the past. The ever-shrinking forests are ideal hiding places/retreats for armed opposition groups. Many national parks in Africa are associated with the presence of rebels, and conflicts extend over a much larger arena than they used to. Currently there are rebel groups in Kahuzi-Biega National Park, Garamba National Park, Upemba National Park, Salonga National Park, and Virunga National Park in DRC. In Uganda, rebels are found in the Ruwenzori National Park and Semuliki National Park. Protected areas that straddle international borders are particularly at risk as people can move back and forth between countries more freely.

Civil war erupted at independence in both Rwanda and DRC during the 1960s and probably had an impact on the gorillas. It is known that 
gorillas around the volcano Mikeno in DRC dropped in number between 1960 and 1971-73 (Weber \& Vedder, 1983). In 1990, the Rwandan Patriotic Front (RPF), a movement created by a group of refugees who fled the civil war in Rwanda in the 1960s, invaded Rwanda from Uganda and based some of its troops in the forest between the volcanoes Sabyinyo and Muhabura. The Rwandan army at the time used to launch shells into the forest to try to dislodge the RPF. In 1994, the RPF took power following the genocide, at which point many of the local people fled into the forest and into Zaire (now DRC). Refugee camps housing hundreds of thousands of people were established near the Virunga Volcanoes and firewood collection led to the destruction of the forest near these camps before international attention was focused on this issue. The bulk of the refugee population did not return to Rwanda until late 1996. Between late 1994 and late 1996 the security situation in the volcanoes was relatively calm. During 1997-99 there were regular incursions by the militias (called the "Interahamwe") that were involved in the genocide, and retaliatory strikes by the Rwandese army. In 1997 and 1998, the Interahamwe used the Parc National des Volcans as a base to launch attacks into the Ruhengeri and Gisenyi prefectures. Local people stopped farming along the park boundary and moved to "internally displaced peoples' camps". Consequently there were many people living in the park with little access to food except what they could find or grow in the forest. Much of the population moved back and forth between the forest and their homes to escape the killings and the crossfire. Many established huts and even small farms in parts of the forest. Since early 1999 the security on the Rwandan side has improved greatly but the DRC sector of the Virungas is still insecure and military escorts are needed to enter this part of the forest.

\section{Research assessing and monitoring threats}

What research, either based from Karisoke Research Center or taking place in and around the Virungas, has addressed some of the threats highlighted above and how did it contribute to better conservation? It can be argued that all research information can potentially be used to improve conservation in some way but we will confine ourselves here to summarizing projects we consider to have addressed issues directly pertinent to conservation.

Several of the research topics described deal with socioeconomic studies of the local human population. Karisoke Research Center historically has not been directly involved in all of the socioeconomic research but has collaborated closely with the projects that have undertaken these studies. Although we present the results of some socioeconomic studies, this is an 
area that needs much more research effort and could be expanded in future.

\section{Projet RRAM - research on water catchment and the ecological role of the Parc National des Volcans}

A project called "Ruhengeri and its Resources" (Projet RRAM) operated in Ruhengeri in the mid 1980s, supported by USAID. This project was established by Bill Weber following some of his work at Karisoke Research Center, and it provided a wealth of data on the ecological value of the forest (Weber, 1987a). The Parc National des Volcans is protected by a dense cover of vegetation that controls flooding, landslides, and erosion. A high level of rainfall is generated in the volcanoes, and this rain is captured in a way that does not provoke erosion - there is a gradual release of water into the surrounding areas, and thus a perennial supply of clean water. In a survey carried out by the Projet RRAM, 50\% of farmers reported that agricultural productivity in Ruhengeri was declining, and 19\% of them attributed this to erosion in the years following a loss of $54 \%$ of the surface area of the park. The Parc National des Volcans forms only $0.5 \%$ of Rwanda's surface area but contributes an estimated $10 \%$ of the water catchment (Weber, 1979).

Weber documented that the regional land use could not increase in any significant way in the Ruhengeri prefecture. Even converting the entire park to agricultural land would only provide extremely marginal land for the equivalent of one year of Rwanda's human population growth. The slopes of the volcanoes would be too steep for sustainable agricultural production and could only provide short-term benefits rather than the longer-term benefits of gorilla tourism. This ecosystem approach to research in the Virungas, rather than a focus on gorillas, provided valuable information to bolster the arguments for keeping the forest cover on the volcanoes.

\section{Gorilla population censuses}

Population monitoring of any rare species is essential if conservation practitioners are to be able to assess the effectiveness of their management. Consequently regular censuses were carried out from the start of the gorilla research. In 1963 Schaller estimated that 400-500 gorillas lived in the Virungas. Schaller developed a census technique using nest counts and measurements of dung to estimate population size (Schaller, 1963; Weber \& Vedder, 1983; McNeilage et al., 2001). Each night an adult or juvenile gorilla constructs a nest and by following fresh trail until they find the most recent nests, researchers can obtain a total count of animals in a protected 
area. Usually three counts are made for each group in case any nests are missed. By measuring the size of the dung the gorillas deposit in the nest a researcher can obtain a measure of the structure of the population because size of the dung is related to size of the animal (Schaller, 1963). Subsequent censuses in 1971-73 and 1976-78 raised the alarm by clearly showing drastic declines in the gorilla population to about 252 animals (Harcourt \& Fossey, 1981; Weber \& Vedder, 1983). Following the launch of the Mountain Gorilla Project and ecotourism to the gorillas, subsequent censuses in 1981, 1986, and 1989 showed numbers increasing again to 310 individuals (Sholley, 1990). To make an accurate count in the Virungas, all three habitat countries must be surveyed simultaneously, since gorilla groups move freely between Rwanda, DRC and Uganda. A follow-up to the most recent 1989 census was made impossible by the civil war and the laying of anti-personnel land mines on the international border between Rwanda and DRC. In 1994 a Rwandan demining team began operating in the Parc National des Volcans with financial support from the International Gorilla Conservation Program, and cleared all the mines, but insecurity in the region remained an obstacle to carrying out a census.

Ten years after the last census, we can not give a precise number for the current gorilla population in the Virungas. The habituated groups monitored on a daily basis between the volcanoes Karisimbi and Sabyinyo, and in Uganda, are in good health and reproducing, although the impact of recent insecurity on groups ranging elsewhere in the Virungas is unknown. An update on the status of the gorilla population is much needed and is a top priority of the park managers and conservation organizations.

\section{Socioeconomic research}

Socioeconomic studies are important because the needs of the members of the local community who live around the Virunga Volcanoes and their attitudes towards the forest and conservation can determine the success or failure of any conservation project. People's attitudes towards protected areas and conservation will be strongly affected if they suffer costs as a result of the presence of the park, such as crop-raiding by wild animals or increased risk to themselves from large animals.

Attitudes towards the forest by the local political authorities will also affect whether further land is excised from the forest. Given that the entire Virunga conservation area (Rwanda, DRC, and Uganda) is currently protected by National Park status, it would seem that there is little danger of habitat loss; however, even now, the integrity of these national parks is not assured. Prior to and during the civil wars in Uganda in the 1980s, 
people encroached on the then Mgahinga Game Reserve and farmed inside its boundaries (Butynski et al., 1990). In 1994, the siting of the world's largest refugee camp on the edge of the Virunga National Park enabled people to enter the forest and harvest fuelwood illegally, resulting in the deforestation of about $113 \mathrm{~km}^{2}$ of the park in DRC (Henquin \& Blondel, 1996). In Rwanda, local authorities suggested use of part of the park around the volcano Sabyinyo for human resettlement in 1996. This was prevented through prompt action by the government in Kigali. None the less, illegal encroachment remains a serious threat at the edges of the park.

Influencing attitudes so that the likelihood of habitat loss is lessened is therefore an important task for a park warden and his staff. Local attitudes can be influenced positively via perceived benefits, and negatively through losses attributed to having a national park on their doorstep. Perceived benefits or losses are usually, but not exclusively, based on economic measures.

\section{Local attitudes}

People living around the Virungas resent being prevented from obtaining certain products that they obtained in the past, such as firewood, building materials (bamboo, vines, poles), medicinal plants, bushmeat, and water. In the 1980s, Weber $(1981,1987 b)$ researched people's attitudes towards the park. Using a questionnaire survey he showed that people strongly objected to the presence of the park because of these perceived losses.

In addition negative attitudes towards the parks are exacerbated when people suffer crop damage caused by animals venturing out of the forest at night to feed in their fields. In 1996, a survey of farmers' attitudes to crop-raiding animals also examined measures taken to combat them (Plumptre \& Bizumuremyi, 1996). Local people were asked to identify which animals were the greatest threat to their crops by interviewing households within $2.5 \mathrm{~km}$ of the park boundary. Buffalo (Syncerus caffer) were considered to be the greatest problem up to $2.0 \mathrm{~km}$ from the park (Figure 14.1). Whether this species is responsible for the greatest economic loss is doubtful, but people may view buffalo as the main threat because they are dangerous to human life and can reduce their freedom of movement at night. In the past elephants (Loxodonta africana) were more of a threat than they are today because their numbers were once much greater, whereas they have now been drastically reduced in the Virungas. 


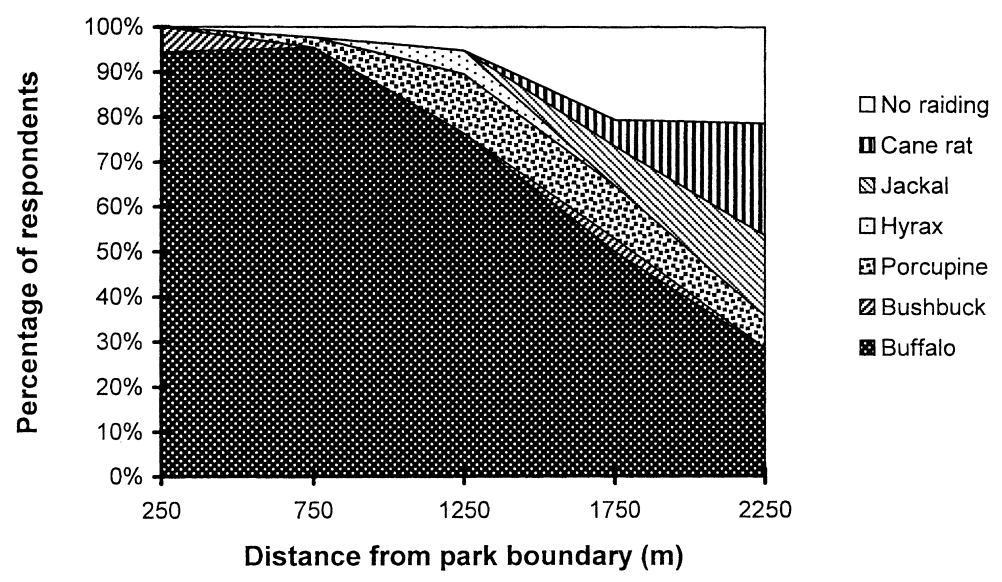

Figure 14.1. The percentage of respondents who labeled a particular species as the worst crop-raider. The figure shows how responses varied with distance $(\mathrm{m})$ of the household from the park boundary.

\section{Responding to negative attitudes}

In the 1980s, the Mountain Gorilla Project initiated an education program in Rwanda to increase awareness of the international importance of the gorillas, the economic benefits of wildlife from tourism, and the ecological benefits of the forest. Weber (1987a) carried out a follow-up survey to the one mentioned above and showed that people's attitudes changed significantly following this education program, despite the fact that little revenue from tourism went directly to people who lived around the park. The main benefit to the local population was from employment opportunities. Currently about 80 government-employed guides and guards and 20 Karisoke Research Center trackers are employed in Rwanda with a few additional administrative staff for the national parks agency. Employment by the tourist industry also increased with the hiring of porters and the employment of hotel staff, drivers of vehicles, and other associated spin-offs. A few people profit by selling crafts to tourists.

In the 1990s, the conservation community placed great emphasis on the economic benefits that accrue to local communities living around national parks. In Uganda several Integrated Conservation Development Projects have been established including one around a park with gorillas, the Bwindi Impenetrable National Park. Sharing revenue from tourism and the collection of non-timber forest products is being practiced around this park in southwest Uganda but the dollar value that each individual receives is very small when averaged across the population. Here the revenues are used to fund community projects around the park rather than 
provide an individual with direct employment. With human densities of 300-600 people per $\mathrm{km}^{2}$ around the Parc National des Volcans and Bwindi, it is going to be very difficult to generate benefits of financial significance, if the profits are shared equally. However, it is better that some revenue sharing takes place than none at all.

Another tool that has been used to improve local people's attitudes in Uganda has been to allow limited use of certain areas of the forest through the creation of multiple-use zones, where people are allowed to place beehives for honey and harvest medicinal plants. Multiple-use zones are also being proposed for Mgahinga National Park in the Virungas. A recent census of gorillas in Bwindi found that gorillas were not present in the multiple-use zones (McNeilage et al., 2001), and although there is no direct evidence that human use is preventing gorillas using this area, it is possible that such use of the forest may have the effect of reducing the habitat available to gorillas. This practice should be monitored carefully. Of greater concern is a recent report (CARE, 1998) which showed that despite the creation of multiple-use zones in Bwindi, $68 \%$ of people still felt that the costs of living close to the park outweighed the benefits. This shows the importance of research in monitoring people's attitudes towards conservation when implementing community conservation projects.

\section{Poaching}

Research into several aspects of poaching includes assessing the frequency and location of snares in the Parc National des Volcans to determine whether more effective patrolling techniques can be developed. An examination of the number of snares found in different regions of the Parc National des Volcans by Office Rwandais du Tourisme et des Parcs Nationaux (ORTPN) guards between 1982 and 1988 (T. Lawrence, unpublished data from Mountain Gorilla Project) shows the markedly higher numbers of snares taken annually from sector III (Figure 14.2). This may be partly a result of higher patrol effort (both ORTPN and Karisoke Research Center staff patrolled this sector) but joint patrols did not take place until 1986 before which patrol effort was similar for each sector. This part of the park may have had higher ungulate populations, because it had been protected for longer with the presence of the Karisoke Research Center, and so consequently may have attracted more poachers. Analysis of the impact of patrol effort shows that as the number of patrols increased more snares were found, but that the number of snares per patrol dropped significantly after about 20 patrols per month (Figure 14.3). Data on snares collected at Karisoke Research Center show that during the year there are peaks in snares found around Christmas and Easter (N. Gerald- 


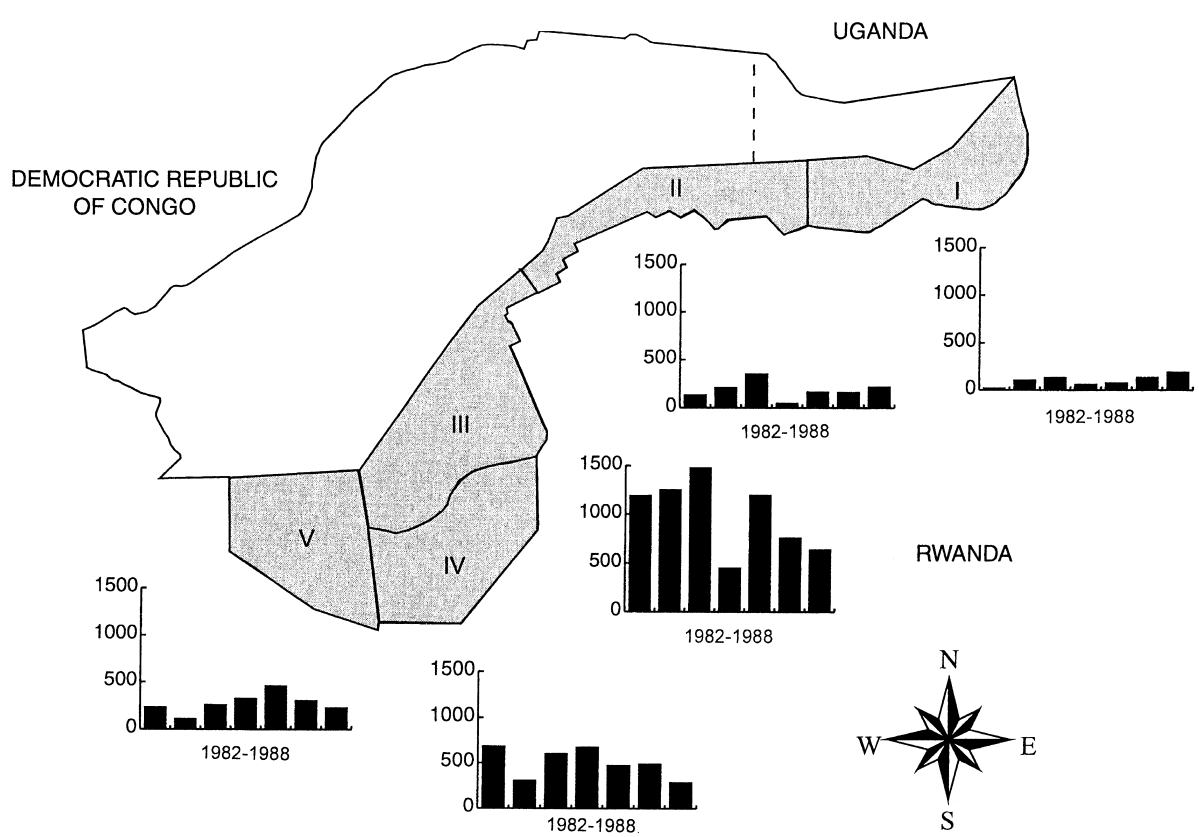

Figure 14.2. The number of snares collected annually in different sectors of the Parc National des Volcans, Rwanda between 1982 and 1988. Sector III includes snares from the Karisoke Research Center and ORTPN (Rwandan parks) guards from 1986. Prior to 1986 only data for snares collected by ORTPN guards could be found.

Steklis, personal communication), times when households often hope to eat meat (A. Plumptre, unpublished data). The number of snares found in the Virungas in the 1989 gorilla census was far higher than the number found in Bwindi in 1997 despite a much higher guard density in the Virungas. Why this was the case is difficult to understand but given that ungulate sightings and dung were far less abundant in Bwindi it may not be as worthwhile to set snares (McNeilage et al., 1998).

A recent survey measured the socioeconomic status of poachers in the community adjacent to the Parc National des Volcans (Plumptre \& Bizumuremyi, 1996). This research showed that poachers were mainly targeting bushbuck (Tragelaphus scriptus) and black-fronted duiker (Cephalophus nigrifrons) although a few also set snares for buffalo and hyrax (Dendrohyrax arboreus). Gorillas are not targeted, probably because traditionally Rwandans do not eat primate meat, and because these people had been exposed to an environmental education program. However, snares set for other animals can easily trap a gorilla's hand or foot and have led to the death or injury of many gorillas. Responses to questions 


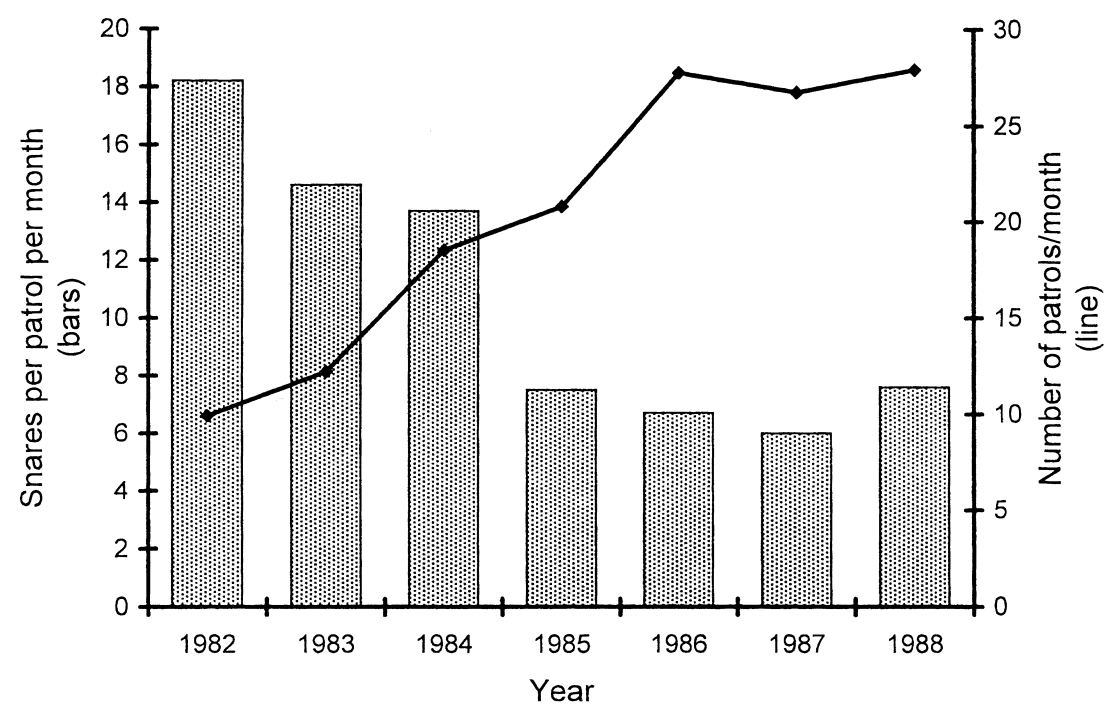

Figure 14.3. The mean number of snares recovered per patrol each month (bars) in the Parc National des Volcans and patrol effort (line) between 1982 and 1988.

about hunting wild animals in their fields showed that $28.7 \%$ of people living within $2.5 \mathrm{~km}$ of the boundary of the Parc National des Volcans admitted to hunting animals when they came into their fields and $27.6 \%$ admitted to setting snares or pitfall traps (Table 14.1). Additionally, 33.1\% of people interviewed admitted to buying bushmeat although nobody said they had killed or eaten gorillas (Plumptre \& Bizumuremyi, 1996). A preference for the taste of bushmeat will always be important in the decision about whether to buy it or not, but often it is the cost that really determines a sale. Data from Ruhengeri show that bushmeat is consistently cheaper than domestic meat. In fact domestic meat prices rose between 1990 and 1996 from about 350 Rwandan francs (FRw) to $450 \mathrm{FRw} / \mathrm{kg}$, whereas bushmeat prices dropped over the same period from 60 to $40 \mathrm{FRw} / \mathrm{kg}$ (Plumptre \& Bizumuremyi, 1996; Plumptre et al., 1997). The rate of buying bushmeat increased following the genocide and the rate of selling of bushmeat per hunting effort also increased (Plumptre et al., 1997), partly as a result of these price changes. Farmers who admitted to poaching in the park had significantly smaller fields, and fewer domestic livestock than the average household (Table 14.2). In addition, those people who admitted to poaching lived nearer the edge of the park. Given this fact and their small field area, people who poach will be most vulnerable to crop-raiding losses and this may be one of the factors that drive 
Table 14.1. The percentage of respondents who admitted to "illegal" activities concerned with hunting of bushmeat around the Parc National des Volcans

\begin{tabular}{llll}
\hline \hline & West of park & East of park & Combined \\
\hline Percent admitting to snaring (fields or park) & 25.6 & 29.7 & 27.6 \\
Percent admitting to hunting in fields & 20.0 & 37.4 & 28.7 \\
Percent admitting to hunting in park & 7.8 & 14.3 & 11.0 \\
Percent admitting to buying bushmeat & 18.9 & 47.3 & 33.1 \\
\hline \hline
\end{tabular}

The responses of people in the west (between Karisimbi and Sabyinyo) are compared with those in the east (between Sabyinyo and Muhabura). This split was made because people in the east tended on average to have more wealth and access to job opportunities. It was felt it was important to look at those people who admit to setting snares as well as those hunting in fields/park because of the impact snares can have on gorillas and because people might admit to using snares if they did not have to state where they snared.

Table 14.2. The results of Mann-Whitney $\mathrm{U}$ tests and $\chi^{2}$ tests between measures of wealth and whether a person admits to snaring (in their fields or in the park) or hunting in their fields or the park

\begin{tabular}{llll}
\hline \hline & Setting snares & Hunting in fields & Hunting in park \\
\hline Distance from park & $\mathrm{ns}$ & $\mathrm{ns}$ & $-* *$ \\
Number of children & $\mathrm{ns}$ & $+*$ & $\mathrm{~ns}$ \\
Number of sheep & $\mathrm{ns}$ & $\mathrm{ns}$ & $-*$ \\
Number of goats & $\mathrm{ns}$ & $\mathrm{ns}$ & $-*$ \\
Number of cattle & $\mathrm{ns}$ & $\mathrm{ns}$ & $\mathrm{ns}$ \\
Livestock biomass & $\mathrm{ns}$ & $\mathrm{ns}$ & $-*$ \\
Area of fields & $-*$ & $\mathrm{~ns}$ & $-* *$ \\
Residence time & $\mathrm{ns}$ & $+^{*}$ & $\mathrm{~ns}$ \\
Employed & $-*$ & $\mathrm{~ns}$ & $\mathrm{~ns}$ \\
Owns radio & $\mathrm{ns}$ & $\mathrm{ns}$ & $\mathrm{ns}$ \\
Owns bicycle & $\mathrm{ns}$ & $\mathrm{ns}$ & $\mathrm{ns}$ \\
\hline \hline
\end{tabular}

$+=$ positively associated with the measure,$-=$ negatively associated. $\mathrm{ns}=$ not significant, $*=p<0.05, * *=p<0.01$.

them to poach. It is probable that the frustrations people sense with crop-raiding animals lead to negative attitudes towards the park, increasing the probability that they will buy bushmeat. Consequently conservation managers need to address the crop-raiding problem for long-term success in conservation. Community conservation programs established around the Parc National des Volcans should target the poorer members of society and find alternative methods of income generation. This will not solve the whole problem because some people admitted to hunting for 
cultural reasons and because they liked the taste of the bushmeat, but it could help reduce the pressure.

\section{Impacts of tourism}

In the early 1980s, tourism to visit habituated gorillas was organized as an economic alternative to cutting the forest for other uses, thus providing a persuasive argument against the threat to excise yet more land for cattle pasture (Vedder, 1989). Gorilla tourism became a great success in terms of revenue for Rwanda, increased protection of the park, and close surveillance of additional gorilla groups (Harcourt, 1986; Vedder, 1989; Weber, 1993).

\section{Benefits of tourism}

Tourism enabled ORTPN, the National Parks authority in Rwanda, not only to become self-financing by the end of the 1980s, but also to subsidize salaries, patrols, and operating costs in the other protected areas of Rwanda, Akagera National Park and the Nyungwe Forest Reserve. Following the international release of the film "Gorillas in the Mist", the price of gorilla permits was increased from $\$ 120$ to $\$ 170$ (Sholley, 1988) and more recently to $\$ 250$.

International publicity surrounding the gorillas and the advent of organized tourism brought many visitors to Rwanda and made tourism the third highest foreign-currency earner for this country after tea and coffee, at nearly $\$ 1$ million per annum (Weber, 1993). Monitoring of habituated groups for tourism increased surveillance in the park by leading to the presence of several teams of parks staff in the forest (McNeilage, 1996). Daily observations facilitated rapid intervention when necessary, for example, to remove snares. With increased protection from poachers, more infants per adult female were recorded in groups that were habituated and visited by tourists (Harcourt \& Fossey, 1981), and in 1986 the population was seen to be increasing for the first time in three decades (Vedder \& Weber, 1990). International awareness and concern for the plight of gorillas enhanced through tourism also generated funds for conservation activities and research. The gorilla became a national symbol and was depicted everywhere in Rwanda: on postcards, stamps, cloth, murals, and carvings in tourist shops. Today the Rwandese passport, visas for foreigners, and bank notes all feature gorillas.

Some of the proceeds of the tourism benefit the local community around the parks by providing employment or boosting the economy (food, hotel bills, etc). In Uganda, revenue sharing of tourism receipts operates around Uganda's Mgahinga Gorilla and Bwindi Impenetrable National Parks, 
and has probably led to greater support for these parks by the local community. It has been agreed in principle, although yet to be put into practice in Rwanda, that profits generated through tourism should also be shared with people living around park, or used to fund schools and health centers for the local population.

\section{Dangers linked to tourism}

Pressures from tourism are high as it is a lucrative business, and some people question the continued justification for gorilla viewing as a conservation measure. Butynski \& Kalina (1998) examined various aspects of gorilla tourism, including the role of money and politics. They conclude that gorilla tourism is likely to be sustainable only:

- where conservation is given priority over economic and political concerns

- where decisions affecting tourism are based on sound and objective science

- where scientifically formulated regulations governing visits are rigorously controlled.

Even before tourism began, impacts of visits on the gorillas' behavior were feared, for example changing the gorillas' ranging patterns, impeding the transfer of females to other groups, and hindering reproduction (Vedder, 1989). As tourism was being developed the groups were monitored by researchers as the size of groups of tourists was increased to evaluate whether the gorillas were changing their behavior drastically. Stress to the animals can be provoked during the habituation process or through regular contact with unfamiliar humans, which could potentially result in immunosuppression or reductions in reproductive success. It is acknowledged that these impacts have never been adequately evaluated. However, extrapolation from research on population demographics carried out at Karisoke Research Center, indicates that tourism has not been deleterious to the gorillas' overall health, behavior, and ecology. Any negative impacts seem to have been outweighed by improved monitoring and protection.

Habituation, the loss of fear of humans, could render gorillas extremely vulnerable in dangerous situations. Sadly this was the case, when habituated gorillas in the Virunga national park were shot at point-blank range in 1995. Also, in the poaching of eastern lowland gorillas in the KahuziBiega National Park, habituated gorillas were some of the first killed during 1999-2000. An entire group was wiped out with a few rounds of machine gun fire (Yamagiwa, 1999). 
Until recently we have relied on speculation, extrapolation, and common sense to evaluate the risks of disease transmission from humans to gorillas. Tourism introduced a new element to that threat. A study commissioned by the International Gorilla Conservation Program (Homsy, 1999) reviewed tourism regulations in light of epidemiological data and the risk of disease transmission between people and gorillas. Studies of captive gorillas show they have a definite susceptibility to human diseases, but not the same resistance as humans (Homsy, 1999). As a result of this shared susceptibility, certain human pathogens can affect gorillas, not only respiratory (measles, herpes, pneumonia) but also equally important enteric diseases (polio, salmonella). Homsy concluded that: "together with the high population pressure surrounding the parks, disease exposure ironically makes tourism one of the single greatest threats to mountain gorilla survival" and that "the best hope for a least damaging tourism program resides in the widespread sensitization, awareness and understanding of the catastrophic consequences of unconscious gorilla tourism".

Despite the dangers inherent in tourism, it provides a mechanism for ensuring that the parks and the gorillas are valued for many reasons, and has probably saved the gorillas in the Virunga Volcanoes from further habitat loss or degradation.

\section{Armed conflict}

Research from Karisoke Research Center has investigated two aspects of the civil war in Rwanda. These have focused on the effects of the fighting on animal populations and the effects of the war on staff of conservation organizations.

\section{Effects of civil war on ungulate populations}

To date it has not been possible to measure accurately the impact of the civil war on the gorilla population, but assessments have been made for the more abundant ungulates in the Parc National des Volcans (Plumptre et al., 1997). This study, undertaken in 1996 during a period of calm in northwestern Rwanda, showed that the bushbuck and buffalo populations had not changed greatly in the region of the Karisoke Research Center between 1988-89 and 1996, whilst the black-fronted duiker population had increased. Buffalo counts showed no significant change in any use of habitat type, but bushbuck and black-fronted duikers increased significantly in the alpine habitat at high altitude (Plumptre et al., 1997). However a questionnaire survey of people's impressions of population changes across the entire park, based on crop-raiding frequency, indicated that 
Table 14.3. Crop-raiding frequencies (number of days per year) within 500 meters of the park boundary

\begin{tabular}{lllll}
\hline \hline Animal & Time & West of park & East of park & Combined \\
\hline Buffalo & pre 1994 & $209 * *$ & $175^{* *}$ & $193 \mathrm{~ns}$ \\
& post 1994 & 72 & 353 & 208 \\
Bushbuck & pre 1994 & $268^{* *}$ & $283 \mathrm{~ns}$ & $275^{* *}$ \\
& post 1994 & 15 & 176 & 163 \\
Black-fronted & pre 1994 & $106 *$ & $261^{*}$ & $181^{*}$ \\
duiker & post 1994 & 44 & 132 & 87 \\
Porcupine & pre 1994 & $137 \mathrm{~ns}$ & $268 \mathrm{~ns}$ & $200 \mathrm{~ns}$ \\
& post 1994 & 104 & 258 & 179 \\
\hline \hline
\end{tabular}

Wilcoxon signed ranks tests were used to detect differences before and after 1994. As above the respondents were separated depending on whether they lived in the west or east. $*=p<0.05, * *=p<0.01, \mathrm{~ns}=$ not significant.

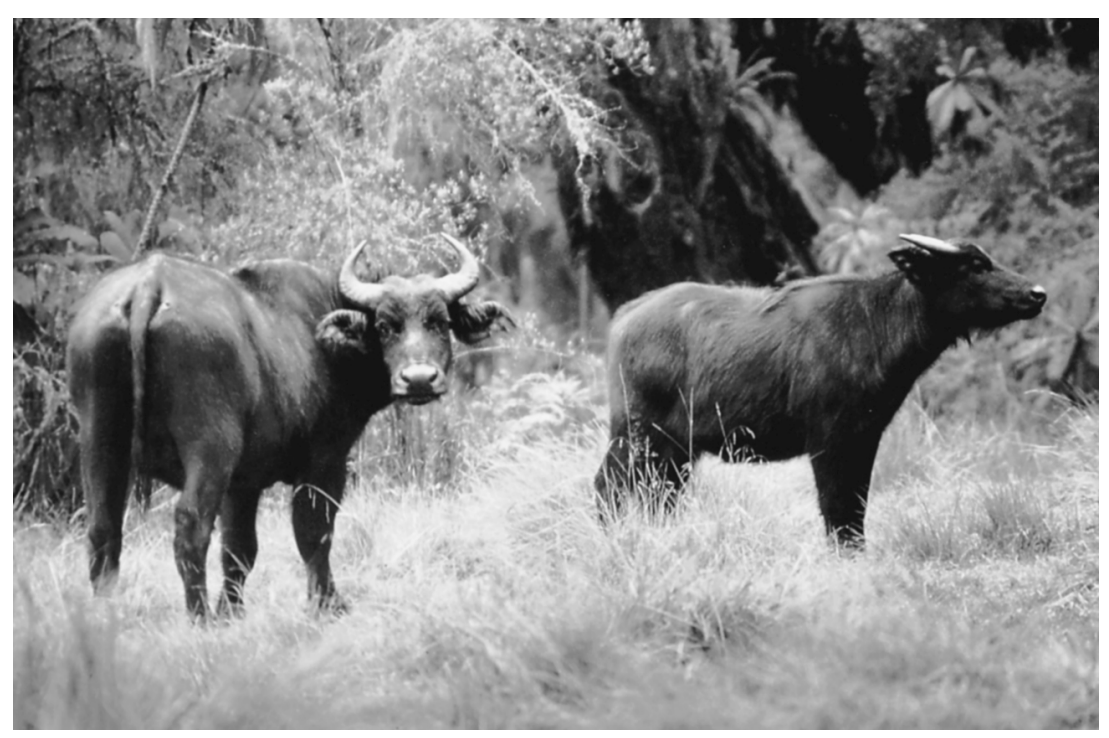

Figure 14.4. Buffalo, one of the large ungulates found in the Virungas, also raid crops. (Photo by A. J. Plumptre.)

certain animal populations had changed and that these had changed in different ways in the west and east of the Virungas (Table 14.3). People's perceptions should be regarded with care and not necessarily equated with reality, but they do give a measure of how people feel crop-raiding is affecting their livelihoods. It is interesting that people in the east reported greater crop-raiding by buffalo following the war whilst those in the west 
reported lower crop-raiding in 1996 (Figure 14.4). At this time a wall was being constructed in Uganda to prevent buffalo crop-raiding which may have led to increased raiding on the Rwandan side.

\section{Impacts of insecurity on staff}

Civil war in Rwanda has made the headlines as a result of the genocide. What lessons can be learned from the attempts to conserve the gorillas and other protected areas in Rwanda that could be applied elsewhere? Why was it that despite the risks to their lives people continued to work to protect these animals? One of us (A. Plumptre) carried out a survey of the staff of the Karisoke Research Center and the Nyungwe Forest Conservation Project (PCFN) in south west Rwanda to determine (1) what had been the effect of the war on these people, (2) what motivated them to continue working, and (3) what international conservation organizations could do better during times of war to help their staff.

Insecurity has been high for longer around the Virungas than in other protected areas in Rwanda such as the Nyungwe Forest. How had the insecurity affected the staff working for these two projects? As a result of the fighting in this region between 1990 and 1999 there have been at least ten deaths of ORTPN staff in Rwanda in the Virungas, 12 deaths of Karisoke Research Center staff, 44 of parks staff of the Institut Congolais pour la Conservation de la Nature (ICCN) in the Virunga National Park, four of ICCN staff in the Kahuzi-Biega National Park in the DRC (N. Mushenzi, personal communication), and one of an ORTPN employee in Nyungwe Forest. Of the Karisoke Research Center staff, 94\% had been robbed (compared with $41 \%$ of PCFN staff) at some point during the war and $88 \%$ had lost a member of their family (compared with $43 \%$ of the PCFN staff). Few of the PCFN staff believed their work had increased the risk to their life (14\%) but $69 \%$ of the Karisoke Research Center staff believed this was the case. This was because people around the Parc National des Volcans were targeted by the Interahamwe if they worked with the government or with organizations that collaborated with the government.

When asked what motivated them to continue working despite the risks to their lives, salary was obviously a prominent response. The regularity of payment was often noted as being as important as the amounts that were paid. Other aspects of the work that provided motivation for many interviewed included the love of nature/work and the importance of their work nationally and internationally. This latter reason is interesting because it means that the education programs that explained the international uniqueness of the mountain gorilla had led to people being prepared to try 
to protect them at great risk to themselves. The Karisoke Research Center staff valued the fact that the project looked after their families during the war and during 1997-99 because life was so much more dangerous for them during this time.

When asked what projects could do for their staff during war situations, by far the greatest response was to try to reduce the risks to their staff. The specific suggestions included helping staff find somewhere safe to live, or another location where they could work more safely. If this was not possible a few of the PCFN staff suggested stopping the work but on the whole most people wanted to try to continue working despite the dangers. Other aspects that were considered to be important were to collaborate with whichever authorities were in power, rather than obviously taking a political stance. Improving communications (such as providing two-way radios for within-park communications and trying to meet with staff wherever possible), and educating the local population during any peaceful interludes about the importance of the forest for their long-term livelihoods, were also considered to be important. Since this study was carried out two-way radio systems have been provided to staff at both the Parc National des Volcans and the Nyungwe Forest.

In Rwanda, appealing to people's national pride in their gorillas has not been anywhere near as prevalent as economic arguments, and yet national pride in gorilla conservation may be more important than any of the hoped-for economic incentives. In this survey, parks staff in the PCFN and Karisoke Research Center stated that one of the factors that kept them working during the civil war was pride in protecting part of their national heritage and the global importance of their forests for conservation. This is often the motivation for conserving animals in the industrialized countries also. Creating positive attitudes is something that the national parks agencies in Rwanda (ORTPN), DRC (ICCN), and Uganda (Uganda Wildlife Authority) should all aspire to, and education programs are very important in addressing these issues.

\section{Effects of insecurity on the gorillas}

Despite civil unrest from 1991 to 1998, it was only during 1997-98 that trackers and park staff were prevented from monitoring the gorillas for a prolonged period. While the habituated gorillas in Rwanda have fared extremely well (one gorilla was shot dead in 1992), it is known that since 1995 at least 18 gorillas have been killed in the Virunga National Park (DRC) either as victims of poachers with firearms or getting caught in crossfire. Remarkably, almost all habituated individuals were accounted for in Rwanda in 1999 after 14 months without any monitoring. Despite an 
acute increase in illegal activities by the local population when Karisoke Research Center and ORTPN staff suspended patrols, the gorillas were visibly in good physical shape - there had been no loss of limbs or life to snares. Many births had occurred in the research groups and there seemed to be a good potential for growth of the population (E.A. Williamson, personal observation). There may have been other less obvious impacts, resulting from the stress of confronting armed combat or fleeing people. The worry now is that diseases that may have been contracted from the human refugees inhabiting the Parc National des Volcans in 1997-98 will have serious long-term impacts on the gorilla population in Rwanda (see Mudakikwa et al., this volume).

\section{Application of behavioral and ecological research to conservation}

The wealth of knowledge gained through studies at Karisoke Research Center forms the basis for this book, yet it is not always evident that "pure" research can provide essential information for practical conservation. Ecological functions of the forest must be demonstrated, management needs have to be established, tourism and other impacts on the ecosystem should be monitored, to enable us to develop and improve tools with which to protect the park and the gorillas. However the importance of behavioral research is becoming increasingly acknowledged for conservation management (Clemmons \& Buchholz, 1997). The following section provides some examples of how various aspects of "pure" behavioral and ecological studies can be "applied" to conservation.

\section{Long-term monitoring of gorillas at Karisoke Research Center}

The long-term research from Karisoke Research Center is one of few continuous studies of an animal population that has spanned several decades. Data on inter-birth intervals and other reproductive parameters are all-important when it comes to assessing rates of change (e.g. Harcourt et al., 1981; Watts, 1991a; Robbins, 1995). Census results and population statistics not only show changes in the actual numbers of gorillas, but reproductive health and potential are indicated by the age-sex composition of the population (e.g. Harcourt \& Fossey, 1981; Weber \& Vedder, 1983). Thus demographic and life history data are especially important for park managers to assess the effectiveness of their activities. Steadily increasing gorilla numbers in the 1980s indicated that conservation actions were having a positive impact.

Similarly, understanding aspects of feeding ecology, nutrition, and ranging behavior (Waterman et al., 1983; Watts, 1987 \& 1991b; Plumptre, $1995,1996)$ is important in determining whether the Virunga population 
could increase in size, and for improving management practices in areas which are not used by gorillas (McNeilage, 1995). For example, ecological data will be crucial to evaluate "underuse" of forest south of Karisimbi (Watts, 1998 a, b). If we are able to assess avoidance of certain areas of the Virungas, park managers may be able to alleviate detrimental conditions and improve the gorillas' chances of survival.

Park managers are able to use the results of research at Karisoke Research Center to interpret dramatic instances of natural behavior, such as infanticide (Fossey, 1984; Watts, 1989), while knowledge of the natural processes of male emigration and female immigration explains transfers and "disappearances" of individuals (e.g. Sicotte, 1993).

One pertinent concern for the mountain gorillas' future is whether the size of their gene pool has been reduced to a level where inbreeding may become an serious problem. Analysis showed that habitat loss is a greater danger to the gorillas than inbreeding, and such studies can guide park managers in consolidating their resources (Harcourt, 1996).

\section{Designing tourism programs and providing baseline information for comparisons with "tourist" groups}

Karisoke Research Center played a critical role in developing the techniques of gorilla habituation. Researchers with experience gained from Karisoke Research Center initiated the tourism program in Rwanda. Part of the success of this program was based on our knowledge of gorilla diet, daily travel distance, and ranging (e.g. Watts, 1984), making it possible to predict group movements and locate the gorillas with relative ease. Predictability of daily activity rhythms was also important for the tourism program, and visits were timed to coincide with gorillas' rest periods when possible, facilitating excellent observation conditions for the visitors.

Continued long-term monitoring of gorillas at Karisoke Research Center provides a baseline from which to judge the impacts of tourism. These data allow park managers to assess whether new or altered behaviors observed in groups visited by tourists might result from stress caused by tourism. Tourism guidelines have been developed through our understanding of gorilla behavior and our awareness of what disturbs them. It is important for park managers to minimize stress to these animals because no one can afford to put at risk such a small population if tourism revenues are to be maintained. Monitoring should be coupled with targeted research to evaluate the impacts of tourism and provide information for managers to ensure that tourism is implemented sustainably. Watts (1998c) demonstrated a strong correlation between rainfall and mortality, and recommended that extra stringent measures to limit disease transmission should 
be taken by anyone, tourists and researchers, visiting gorillas during the rainy season.

The positive integration of research and management will ensure that management decisions are based on sound scientific data. Since 1997, the International Gorilla Conservation Program has organized regional meetings to bring together managers of protected areas from the three Virunga parks, the Parc National des Volcans, the Parc National des Virunga, and Mgahinga National Park, and their partners from non-governmental organizations. During these meetings, tourism regulations have been reviewed to provide managers with input on what is and is not sustainable. Researchers and managers were able to develop together recommendations based on the findings of Homsy (1999).

\section{Providing information for conservation education, fund-raising, and zoos}

The "Karisoke Research Center" gorillas have attracted world-wide attention, fueled through documentary films and magazine articles about their lives. Education programs, both nationally and internationally, rely on information from research projects and Karisoke Research Center has generated the bulk of the information that currently exists about mountain gorilla behavior and ecology.

Public commitment to try to save the mountain gorillas provides funds for the activities of the conservation non-governmental organizations, which benefit the parks in Rwanda and other parks in the region. This high profile attracts visitors to the gorillas, bringing revenue to the country and helping Rwanda develop its pride in its national heritage. A positive image enhanced by a well-managed tourism program stimulates tourism further and generates publicity.

Additionally, lessons learned from the mountain gorillas have helped enormously in the care and management of the large captive population of western lowland gorillas. The gorillas themselves have benefited as their physiological and psychological needs are better understood and catered for (e.g. Watts, 1990).

\section{Future research and linkages at Karisoke Research Center}

One aspect of long-term monitoring that has been lacking is detailed monitoring of gorilla groups visited by tourists. Documenting the dynamics of a larger number of groups would expand our knowledge of the natural variation between groups in the Virunga population. In addition most research has been concentrated in Rwanda and much more work needs to be done in the Virunga National Park in DRC. This park, which 
forms two-thirds of the Virunga forest, is altitudinally and ecologically quite distinct from the Rwandan side, and so data would be more representative of the whole population (McNeilage, this volume).

Whilst the continuation of ecological and behavioral research on the mountain gorillas is important, it is vital that other aspects critical to management of the park are addressed. A park warden faces many issues, including education of the local community, problems with crop-raiding animals, illegal hunting, and community use of certain forest products. Research is an essential requirement for the development of management plans and monitoring actions implemented by park management. The importance of coordinating research and management and closely linking research to management has been emphasized (e.g. Harman 1994; Alexander 1995). Reinforcing links between Karisoke Research Center and park managers will underscore the value of the research center and help address management problems.

\section{Acknowledgements}

The Wildlife Conservation Society and Dian Fossey Gorilla Fund International funded the collection of the new data summarized in this chapter, and we thank the following for help in the collection of some of these data: Jean Bosco Bizumuremyi, Tom Lawrence, Jean Damascène Ndaruhebeye, François Javier Ngarukiyintwari, and Leonidas Ngabayisonga. Several conservation organizations have been involved in the work reported here: Fauna and Flora International, World Wide Fund for Nature, and African Wildlife Foundation supported the Mountain Gorilla Project and now the International Gorilla Conservation Program; Dian Fossey Gorilla Fund International supports the Karisoke Research Center and the Wildlife Conservation Society has supported all the censuses of the gorillas and some of the research projects. We would like to thank the Government of Rwanda and the Office Rwandais du Tourisme et des Parcs Nationaux for permission and support to work in the Parc National des Volcans.

At the end of the 1990s, while the gorillas thrived, many experienced gorilla trackers lost their lives. We would like to dedicate this chapter to Vatiri André, as a representative of those who have died in tragic circumstances in recent years. Vatiri died in 1997, the most difficult period in the lives of the Karisoke Research Center staff, and he symbolized the longterm commitment of the trackers to the fight to save the gorillas. 


\section{References}

Alexander, M (1995) Management planning in relation to protected areas. Parks, 5, 2-11.

Butynski, T M \& Kalina, J (1998) Gorilla tourism: a critical look. In Conservation of Biological Resources, ed. E J Milner-Gulland \& R Mace, pp. 280-300. Oxford: Blackwell Scientific Publications.

Butynski, T M, Werikhe, S E \& Kalina, J (1990) Status, distribution and conservation of the mountain gorilla in the gorilla game reserve, Uganda. Primate Conservation, 11, 31-41.

CARE (1998) Survey of Knowledge and Attitudes of People from Communities Bordering BINP and MGNP. CARE/Development Through Conservation, no. $98 / 391$.

Clemmons, J R \& Buchholz, R (1997) Behavioural Approaches to Conservation in the Wild. Cambridge: Cambridge University Press.

Fossey, D (1983) Gorillas in the Mist. Boston MA: Houghton Mifflin.

Fossey, D (1984) Infanticide in mountain gorillas (Gorilla gorilla beringei) with comparative notes on chimpanzees. In Infanticide: Comparative and Evolutionary Perspectives, ed. G Hausfater \& S B Hrdy, pp. 217-35. New York: Aldine Press.

Goodall, J (1986) The Chimpanzees of Gombe: Patterns of Behaviour. Cambridge MA: Harvard University Press.

Harcourt, A H (1986) Gorilla conservation: anatomy of a campaign. In Primates: The Road to Self-Sustaining Populations, ed K Benirschke, pp. 31-46. New York: Springer-Verlag.

Harcourt, A H (1996) Is the gorilla a threatened species? How should we judge? Biological Conservation, 75, 165-76.

Harcourt, A H \& Fossey, D (1981) The Virunga gorillas: decline of an island population. African Journal of Ecology, 19, 83-97.

Harcourt, A H, Fossey, D \& Sabater Pi, J (1981) Demography of Gorilla gorilla. Journal of Zoology, 195, 215-33.

Harman, D (1994) Coordinating research and management to enhance protected areas. In Proceedings of the 4th World Congress on National Parks and Protected Areas, Caracas, Venezuela, IUCN.

Hastings, B E, Kenny, D, Lowenstine, L J \& Foster, J W (1991) Mountain gorillas and measles: ontogeny of a wildlife vaccination program. In Proceedings of the Annual Meeting of the American Association of Zoo Veterinarians, pp. 198205.

Henquin, B \& Blondel, N (1996) Etude par télédétection sur l'évolution récente de la couverture boisée du Parc National des Virunga. Unpublished report, Laboratoire d'hydrologie et de télédétection, Gembloux, Belgium.

Homsy, J (1999) Ape Tourism and Human Diseases: How Close Should We Get? Report to the International Gorilla Conservation Program. Rwanda.

Hudson, H R (1992) The relationship between stress and disease in orphan gorillas and its significance for gorilla tourism. Gorilla Conservation News, 6, 8-10.

Kalema, G, Kock, R A \& Macfie, E (1998) An outbreak of sarcoptic mange in 
free-ranging mountain gorillas (Gorilla gorilla beringei) in Bwindi Impenetrable National Park, Southwestern Uganda. In Joint Proceedings of the American Association of Zoo Veterinarians and American Association of Wildlife Veterinarians Annual Meeting, Omaha, Nebraska, p. 438 (abstract).

Macdonald, D W (1996) Dangerous liaisons and disease. Nature, 379, 400-1.

McNeilage, A J (1995) Mountain gorillas in the Virunga Volcanoes: ecology and carrying capacity. PhD thesis, University of Bristol.

McNeilage, A (1996) Ecotourism and mountain gorillas in the Virungas. In The Exploitation of Mammal Populations, ed. V J Taylor \& N Dunstone, pp. 334 44. London: Chapman \& Hall.

McNeilage, A, Plumptre, A J, Brock-Doyle, A \& Vedder, A (1998) Bwindi Impenetrable National Park, Uganda Gorilla and Large Mammal Census, 1997. Wildlife Conservation Society, Working Paper No. 14.

McNeilage, A, Plumptre, A J, Brock-Doyle, A \& Vedder, A (2001). Bwindi Impenetrable National Park Uganda: mountain gorilla census. Oryx, in press.

Moss, C (1988) Elephant Memories. London: Elm Tree Books.

Plumptre, A (1995) The chemical composition of montane plants and its influence on the diet of the large mammalian herbivores in the Parc National des Volcans, Rwanda. Journal of Zoology, 235, 323-37.

Plumptre, A J (1996) Modelling the impact of large herbivores on the food supply of mountain gorillas and implications for management. Biological Conservation, 75, 147-55.

Plumptre, A J \& Bizumuremyi, J B (1996) Ungulates and hunting in the Parc National des Volcans, Rwanda: the effects of the Rwandan civil war on ungulate populations and the socioeconomics of poaching. Unpublished report to the Wildlife Conservation Society.

Plumptre, A J, Bizumuremyi, J B, Uwimana, F \& Ndaruhebeye, J D (1997) The effects of the Rwandan civil war on poaching of ungulates in the Parc National des Volcans. Oryx, 31, 265-73.

Robbins, M M (1995) A demographic analysis of male life history and social structure of mountain gorillas. Behaviour, 132, 21-47.

Sarmiento, E E, Butynski, T M \& Kalina, J (1996) Gorillas of Bwindi Impenetrable Forest and the Virunga Volcanoes: taxonomic implications of morphological and ecological differences. American Journal of Primatology, 40, 1-21.

Schaller, G B (1963) The Mountain Gorilla: Ecology and Behavior. Chicago: University of Chicago Press.

Sholley, C R (1988) Annual report of the Mountain Gorillas Project. Unpublished report.

Sholley, C R (1990) Census of the mountain gorillas in the Virungas of central Africa. Unpublished report.

Sicotte, P (1993) Inter-group encounters and female transfer in mountain gorillas: influence of group composition on male behavior. American Journal of Primatology, 30, 21-36.

Thorne, E T \& Williams, E S (1988) Disease and endangered species: the blackfooted ferret as a recent example. Conservation Biology, 2, 66-74.

Vedder, A (1989) In the hall of the mountain king. Animal Kingdom, 92, 30-43. 
Vedder, A \& Weber, A W (1990) The Mountain Gorilla Project. In Living with Wildlife: Wildlife Resource Management with Local Participation, ed. A Kiss, World Bank Technical Publication 130, pp. 83-90, Washington DC: World Bank.

Waterman, P, Choo, G, Vedder, A L \& Watts, D P (1983) Digestibility, digestioninhibitors and nutrients of herbaceous foliage and green stems from an African montane flora and comparison with other tropical flora. Oecologia, 60, 244-9.

Watts, D P (1984) Composition and variability of mountain gorilla diets in the Central Virungas. American Journal of Primatology, 7, 323-56.

Watts, D P (1987) Effects of mountain gorilla foraging activities on the productivity of their food plant species. African Journal of Ecology, 25, 155-63.

Watts, D P (1989) Infanticide in mountain gorillas: new cases and a reconsideration of the evidence. Ethology, 81, 1-18.

Watts, D P (1990) Mountain gorilla life histories, reproductive competition, and sociosexual behavior and some implications for captive husbandry. Zoo Biology, 9, 185-200.

Watts, D P (1991a) Mountain gorilla reproduction and sexual behavior. American Journal of Primatology, 24, 211-18.

Watts, D P (1991b) Strategies of habitat use by mountain gorillas. Folia Primatologica, 56, 1-16.

Watts, D P (1998a) Long-term habitat use by mountain gorillas (Gorilla gorilla beringei). I. Consistency, variation, and home range size and stability. International Journal of Primatology, 19, 651-80.

Watts, D P (1998b) Long-term habitat use by mountain gorillas (Gorilla gorilla beringei). II. Reuse of foraging areas in relation to resource abundance, quality, and depletion. International Journal of Primatology, 19, 681-702.

Watts, D P (1998c) Seasonality in the ecology and life histories of mountain gorillas (Gorilla gorilla beringei). International Journal of Primatology, 19, 929-48.

Weber, A W (1979) Conservation of the Virunga gorilla. Wildlife News (African Wildlife Foundation), 14, 7-9.

Weber, A W (1981) Conservation of the Virunga gorillas: a socio-economic perspective on habitat and wildlife preservation in Rwanda. MSc thesis, University of Wisconsin.

Weber, A W (1987a) Ruhengeri and its Resources: An Environmental Profile of the Ruhengeri Prefecture. Kigali: Environmental Training and Management in Africa/USAID.

Weber, A W (1987b) Socio-ecological factors in the conservation of afromontane forest reserves. In Primate Conservation in the Tropical Rain Forest, ed. C Marsh \& R Mittermeier, pp. 205-29. New York: Alan R. Liss.

Weber, A W (1993) Primate conservation and ecotourism in Africa. In Perspectives on Biodiversity: Case Studies of Genetic Resource Conservation and Development, ed. C S Potter, J I Cohen \& D Janczewski, pp. 129-50. Washington DC: American Association for the Advancement of Science Press.

Weber, A W \& Vedder, A L (1983) Population dynamics of the Virunga gorillas 
1959-1978. Biological Conservation, 26, 341-66.

Wilkie, D S \& Carpenter, J (1999) The impact of bushmeat hunting on forest fauna and local economies in the Congo Basin: a review of the literature. Biodiversity and Conservation, 8, 927-55.

Yamagiwa, J (1999) Slaughter of the gorillas in the Kahuzi-Biega park. Gorilla Journal, 19, 4-6.

Young, T P (1994) Natural die-offs of large mammals: implications for conservation. Conservation Biology, 8, 410-18. 
Downloaded from Cambridge Books Online by IP 139.153.14.250 on Sun Mar 11 18:16:20 GMT 2012 http://dx.doi.org/10.1017/CBO9780511661631.015 Cambridge Books Online @ Cambridge University Press, 2012 